\title{
THE INTERMEDIATION ROLE OF CENTRAL CYCLOOXYGENASE PRODUCTS TXA2, PGF $2 \alpha$, PGE, AND PGD IN OREXIN-EVOKED CARDIOVASCULAR EFFECTS
}

\section{MERKEZİ SİKLOKSİJENAZ ÜRÜNLERI TXA2, PGF2a, PGE VE PGD'NIIN OREKSIN'İN OLUŞTURDUĞU KARDIYYOVASKÜLER ETKİLERDEKİ ARACILIĞI}

\section{Burcin ALTINBAS ${ }^{1}$}

\section{Özet}

Merkezi olarak enjekte edilen bazı prostaglandinler (PG) ve oreksin (OX) benzer kardiyovasküler yanitlara sahiptir. Yakın zamanda hem merkezi siklooksijenaz (COX) hem de merkezi lipoksijenaz enzimlerinin OX'nin kardiyovasküler etkilerine aracılık ettiğini bildirdik. Bu çalışmada, kardiyovasküler kontrolde aktif olduğu bilinen COX yolağı ürünleri tromboksan (TX) $\mathrm{A}_{2}$, PGD, PGE ve PGF $_{2 \alpha}$ 'nın OX'in tarafindan oluşturulan kardiyovasküler etkilerdeki aracılıklarını araştırmayı amaçladık. İntraserebroventriküler (i.c.v.) OX enjeksiyonu, normotansif erkek Sprague Dawley sıçanlarda kardiyovasküler yanıtları arttırdı. Ayrıca, $\mathrm{TXA}_{2}$ sentez inhibitörü furegrelate, $\mathrm{PGF}_{2 \alpha}$ reseptör antagonisti, $\mathrm{PGF}_{2 \alpha}$-dimetilamin, PGE ve PGD reseptör antagonisti AH6809 ile merkezi ön tedavi, siçanlarda merkezi olarak uygulanan OX ile indüklenen pressör ve taşikardik kardiyovasküler yanıtları kısmen zayıflattı. Sonuç olarak, verilerimiz i.c.v. OX enjeksiyonunun kan basıncını ve kalp atım hızını artırdığını göstermektedir. Ayrıca, TXA 2, PGF $_{2 \alpha}$, PGE ve PGD kısmende olsa, merkezi olarak uygulanan OX ile uyarılmış pressör ve taşikardik yanıtlara aracılık etmektedir. Sonuçlar, merkezi olarak enjekte edilen OX ile uyarılmış pressör ve taşikardik yanıtlara, $\mathrm{TXA}_{2}, \mathrm{PGF}_{2 \alpha}$, PGE ve PGD dışındaki araşidonik asit metabolitlerinin de aracılık edebileceğini göstermektedir.

Anahtar Kelimeler: Oreksin, Tromboksan $\mathrm{A}_{2}$, Prostaglandin $\mathrm{F}_{2 \alpha}$, Prostaglandin E, Prostaglandin D

\section{Abstract}

Centrally injected some prostaglandins $(\mathrm{PG})$ and orexin $(\mathrm{OX})$ produce similar cardiovascular responses. We have recently reported that both central cyclooxygenase (COX) and central lipoxygenase (LOX) enzymes mediate the cardiovascular effects of OX. In the current study, we aimed to investigate the mediating effects of thromboxane (TX) $\mathrm{A}_{2}, \mathrm{PGD}, \mathrm{PGE}$, and $\mathrm{PGF}_{2 \alpha}$, as COX pathway subproducts known to be active in cardiovascular control, on cardiovascular responses elicited by OX. Intracerebroventricular (i.c.v.) injection of OX increased cardiovascular levels in normotensive male Sprague Dawley rats. Moreover, central pretreatment with the $\mathrm{TXA}_{2}$ synthesis inhibitor furegrelate, $\mathrm{PGF}_{2 \alpha}$ receptor antagonist, $\mathrm{PGF}_{2 \alpha}$-dimethylamine, PGE, and PGD receptor antagonist AH6809 partially attenuated the centrally administered OX -induced pressor and tachycardic cardiovascular responses in rats. In conclusion, our results show that i.c.v. injection of $\mathrm{OX}$ increases blood pressure and heart rate. Moreover, $\mathrm{TXA}_{2}, \mathrm{PGF}_{2 \alpha}, \mathrm{PGE}$, and PGD mediate, at least in part, the centrally applied $\mathrm{OX}$-evoked pressor and tachycardic responses. The results suggest that centrally injected $\mathrm{OX}$-evoked pressor and tachycardia responses may also be mediated by arachidonic acid metabolites other than $\mathrm{TXA}_{2}, \mathrm{PGF}_{2 \alpha}$, PGE, and PGD.

Keywords: Orexin, Thromboxane $\mathrm{A}_{2}$, Prostaglandin $\mathrm{F}_{2 \alpha}$, Prostaglandin E, Prostaglandin D

Geliş Tarihi (Received Date): 21.10.2021, Kabul Tarihi (Accepted Date): 14.11.2021, Basım Tarihi (Published Date): 27.12.2021 'Department of Physiology, Faculty of Medicine, SANKO University, Gaziantep. E-mail: baltinbas@sanko.edu.tr ORCID ID's: B.A.; https:/orcid.org/0000-0002-9534-736X 


\section{INTRODUCTION}

Orexin (OX), also known as hypocretin, is a hypothalamic neuropeptide. It is produced from a common precursor molecule, pre-orexin (De Lecea et al., 1998, pp. 322-327) and binds to two G-coupled receptors, namely OX-1 and OX-2 (Sakurai et al., 1998, pp. 573-585). The OX neurons are located in the hypothalamus and are also found in other regions of the brain (Nambu et al., 1999, pp. 243-260; Peyron et al., 1998, pp. 9996-10015). A considerable body of evidence points to the involvement of the OXergic system in modulating a variety of physiological processes, including food intake and energy expenditure, motivation, circadian rhythms of sleep and wakefulness, memory, cognitive functions, and the neuroendocrine system (Willie et al., 2001, pp. 429-458). In addition, the OXergic system plays an important role in regulating the cardiovascular system (Altinbas et al., 2021, pp. 147239; Samson et al., 1999, pp. 248-253; Shirasaka et al., 1999, pp. 1780-1785). Data from several studies have shown that central injection of OX increases mean arterial blood pressure (MAP), heart rate (HR), renal sympathetic nerve activity, and plasma catecholamines in both awake and anesthetized rats (Samson et al., 1999, pp. 248-253; Shirasaka et al., 1999, pp. 1780-1785). On the other hand, previous studies in this research area have reported that the OX-evoked cardiovascular effects are mediated by the vasopressinergic (Al-Barazanji et al., 2001, pp. 421424), renin-angiotensin (Lin et al., 2002, pp. 619-622), cholinergic (Antunes et al., 2001, pp. 1801-1807), and histaminergic systems (Jochem 2009, pp. 36-37).

AA released from membrane phospholipids by activation of phospholipase A2 (PLA2) forms prostaglandins (PG) or leukotrienes via the COX or lipoxygenase LOX enzyme pathway (Wlodawer \& Samuelsson, 1973, pp. 5673-5678). In previous studies, researchers have documented that AA and its metabolites are involved in cardiovascular control (Tassoni et al., 2008, pp. 220-228). Centrally injected melittin, PLA2 activator and AA increased arterial pressures in normotensive and hypotensive rats (Yalcin \& Erturk, 2007, pp. 103-110; Yalcin \& Aydin, 2009, pp. 447-453; Yalcin et al., 2009, pp. 341-347). It could be considered that centrally injected melittin- or AA -induced cardiovascular responses are the result of possibly central COX pathway products. This is because it is known that as AA -COX pathway products centrally PGE2, PGD2 (Ariumi et al., 2002, pp. 61-64; Hoffman et al., 1981, pp. 899-904; Siren 1982a, pp. 229-234; Siren 1982b, pp. 349-359, Wasserman et al., 1977, pp. 255-269), PGF2 $\alpha$ (Hoffman et al., 1981, pp. 899-904; Siren 1982c, pp. 503-513) and also thromboxane (TX) A2 (Yalcin \& Savci, 2004 pp. 177-187) play a role in cardiovascular modulation. Recently, it was reported that centrally injected OX increased the hypothalamic total extracellular concentration of PG, and central COX and LOX enzymes also mediated OX -induced cardiovascular responses (Altinbas et al., 2021, pp. 147239). However, it is unknown which AA metabolites involved in cardiovascular modulation accompany OX -induced cardiovascular effects. Therefore, in the current study, we investigated the possible role of TXA2, PGE, PGD, and PGF2 $\alpha$, which are synthesized in a substep of the COX -pathway, in the cardiovascular effects induced by centrally administered OX. 


\section{METHODS}

\subsection{Animals}

A total of 98 adult, male Sprague-Dawley rats (280-340 g) obtained from Experimental Animals Breeding and Research Center, Uludag University, Bursa, Turkey, were used for these experiments. Four or five rats were housed per cage under controlled conditions of temperature $\left(20-22{ }^{\circ} \mathrm{C}\right)$, humidity $(60-70 \%)$, and lighting (12 h light/dark cycle) and provided with food and water ad libitum. The Animal Care and Use Committee of Bursa Uludag University approved all experimental procedures in accordance with the National Institute of Health Guide for the Care and Use of Laboratory Animals. (Date 02.12.2014 / No.2014-16/01).

Each animal was studied separately, in a single experiment, and each experimental group consisted of seven rats.

\subsection{Surgical procedures}

Under sevoflurane $\left(2-4 \% / 100 \% \mathrm{O}_{2}\right)$ anesthesia, the left femoral artery was cannulated with heparinized saline $(100 \mathrm{U} / \mathrm{ml})$ using a PE 50 tube filled with heparinized saline $(100 \mathrm{U} / \mathrm{ml})$ to measure mean arterial pressure (MAP) and heart rate (HR). The tip of the tube was covered and exteriorized at the neck of the rat. For i.c.v. drug application, a burr hole was drilled through the skull $1.5 \mathrm{~mm}$ lateral to the midline and $1.0 \mathrm{~mm}$ posterior to the bregma. A 22-gage stainless steel cannula was lowered $4.5 \mathrm{~mm}$ below the skull surface and secured to the skull with acrylic cement. After surgery, the rats were placed in individual cages and allowed to recover from the anesthesia for $4-5 \mathrm{~h}$.

\subsection{Measurement of cardiovascular parameters}

The arterial cannula was connected to a volumetric pressure transducer (BPT 300, BIOPAC Systems Inc., California, USA), which was connected to the MP36 system (BIOPAC Systems Inc.) to measure the cardiovascular parameters of the rats. The rats were allowed to stabilize for 30 minutes before the experiments, and baseline measurements MAP and HR were recorded within this period. Blood pressure was expressed as MAP (mmHg), and HR was expressed as beats per minute (bpm).

\subsection{Experimental protocols}

In the present study, cardiovascular responses to i.c.v. injection of OX were first investigated as the main control for the study. After baseline measurement, the changes in cardiovascular parameters were recorded for the next $60 \mathrm{~min}$ in $\mathrm{OX}(1.5 \mathrm{nmol})$ or saline $(5 \mu \mathrm{l})$ i.c.v. injected normotensive rats. The dose of OX was chosen from the effective dose used in our previous study (Altinbas et al., 2021, pp.147239).

To demonstrate the mediation of central $\mathrm{TXA}_{2}, \mathrm{PGF}_{2 \alpha}, \mathrm{PGE}$ and PGD in cardiovascular effects evoked by $\mathrm{OX}$ in normotensive rats, pretreatment with the $\mathrm{TXA}_{2}$ synthesis inhibitor furegrelate $\left(250\right.$ and $375 \mu \mathrm{g}$; i.c.v.), the $\mathrm{PGF}_{2 \alpha}$ receptor antagonist $\mathrm{PGF}_{2 \alpha}$ dimethylamine (50 $\mu$ g; i.c.v.), PGE and PGD receptor antagonist AH6809 (10 $\mu$ g; i.c.v.), saline (5 $\mu$ l; i.c.v.) or $30 \%$ DMSO ( $5 \mu$; i.c.v.) was performed 5 min before the injection of OX (1.5 nmol; i.c.v.) or saline ( $5 \mu$; i.c.v.), and cardiovascular parameters were recorded for the next $60 \mathrm{~min}$ in rats. 
Altinbas

The dose of furegrelate, $\mathrm{PGF}_{2 \alpha}$ dimethylamine, and AH6809 was chosen from our previous studies (Yalcin et al., 2006, pp. 207-212; Erkan et al., 2017, pp. 117-124).

\subsection{Drugs and i.c.v. injections}

OX (Sigma-Aldrich Co., Deisenhofen, Germany), furegrelate and $\mathrm{PGF}_{2 \alpha}$ dimethylamine (Cayman Chemical Company, Ann Arbor, MI, USA) solutions were prepared in saline, AH6809 (Cayman Chemical Company, Ann Arbor, MI, USA) solution was prepared in 30\% DMSO on the day of experiment.

Intracerebroventricular injections were performed using an injection cannula consisting of 28-gage stainless steel tubing connected to a $10 \mu 1$ microsyringe with polyethylene tubing. The drugs were injected i.c.v. with an injection volume of $5 \mu 1$ over a 60 s period. During injection, an air bubble moving in the polyethylene tubing was closely monitored to ensure that the drug was fully delivered.

\subsection{Statistical analysis}

All values are expressed as mean \pm standard error of the mean (S.E.M.) with $p<0.05$ as significance level. Statistical analysis was done using two-way analysis of variance with repeated measures (RM -ANOVA; two-way) and Bonferroni's post- ANOVA test.

\section{RESULTS}

\subsection{Effects of centrally injected OX on MAP and HR}

Intracerebroventricularly (i.c.v.) injected OX (1.5 nmol) showed pressor and tachycardic effects in normotensive conscious animals ( $p<0.05$; As shown in Figure 1). OX at a dose of $1.5 \mathrm{nmol}$ caused an increase in MAP of approximately $15 \mathrm{mmHg}$. The increase in MAP after injection of OX began in the first few minutes, and the maximum increase in MAP occurred 5 min after administration of OX. The pressure response persisted up to 20 minutes after OX injection (As shown in Figure 1a). Simultaneously, central injection of OX caused an increase in HR, which began in the first minute after injection and lasted up to $15 \mathrm{~min}$, similar to MAP (As shown in Figure 1b). OX at a dose of $1.5 \mathrm{nmol}$ caused an increase of approximately 45 beats/min per minute in HR of the rats (As shown in Figure 1b).

\subsection{The mediating role of central TXA2, PGF 2 , PGE and PGD on the OX -evoked cardiovascular effects}

Central pretreatment with the $\mathrm{TXA}_{2}$ synthesis inhibitor furegrelate $(250$ and $375 \mu \mathrm{g}$; i.c.v.), the $\mathrm{PGF}_{2 \alpha}$ receptor antagonist $\mathrm{PGF}_{2 \alpha}$ dimethylamine $(50 \mu \mathrm{g}$; i.c.v.) and the PGE (EP1, EP2, EP3) and PGD (DP1) receptor antagonist AH6809 (10 $\mu$ g; i.c.v.) did not alter basal cardiovascular parameters in rats. However, pretreatment with frugrelate, $\mathrm{PGF}_{2 \alpha^{-}}$ dimethylamine and AH6809 partially blocked the pressor and tachycardic effects produced by OX $(p<0.05)$ (As shown in Figure 2a,b; 3a,b; 4a,b). 
The Intermediation Role of Central Cyclooxygenase Products $\mathrm{Txa}_{2}, \mathrm{Pgf}_{2 a}$, Pge, and Pgd in Orexin-Evoked Cardiovascular Effects

Altinbas
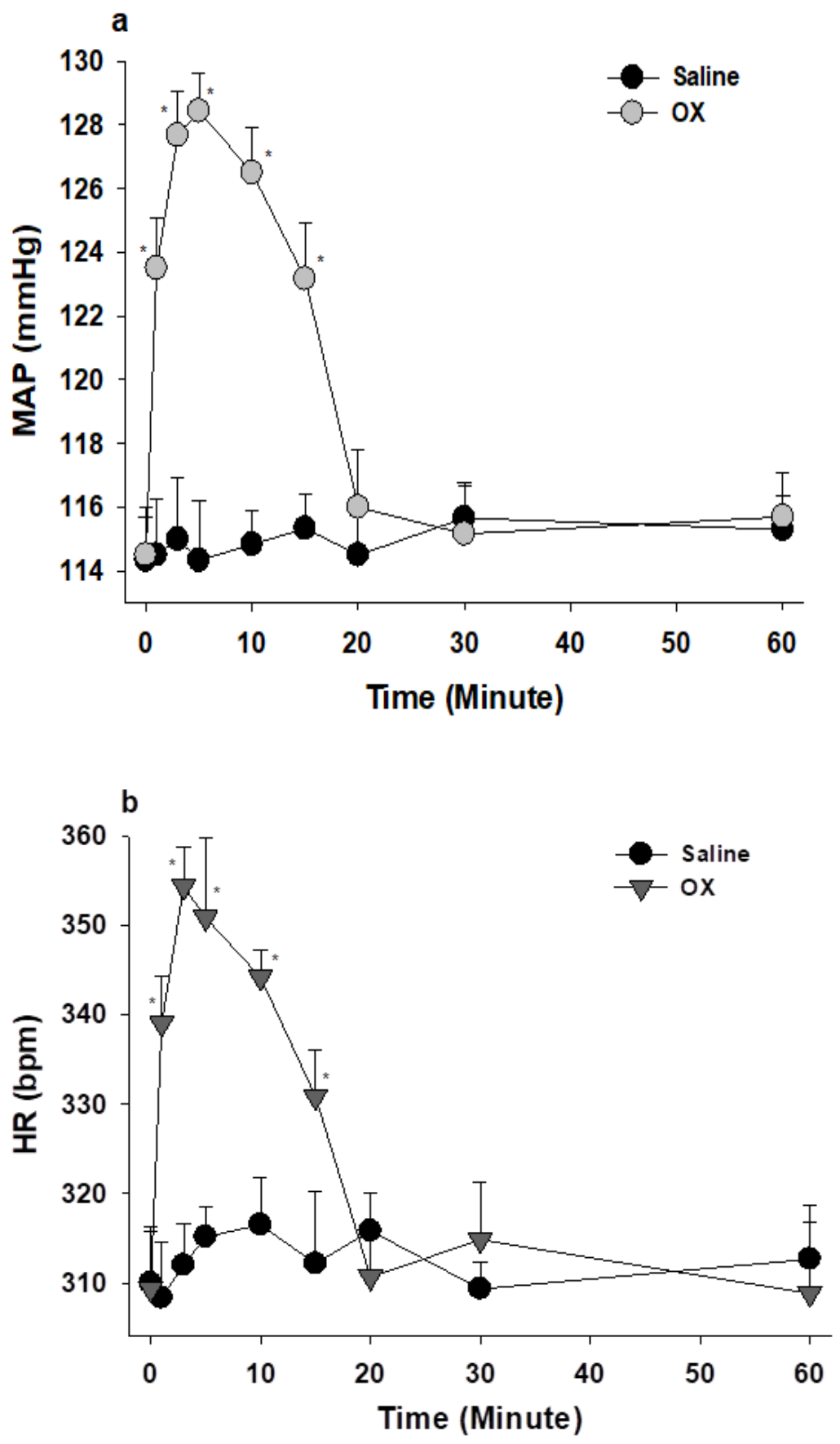

Figure 1. MAP and HR effects of centrally administered OX

OX (1.5 nmol; i.c.v.) or saline (5 $\mu$; i.c.v.) was injected after baseline MAP (a) and HR (b) measurements had been obtained. After the injections, the MAP and HR of the animals were monitored for $60 \mathrm{~min} .{ }^{*} p<0.05$ significantly different from the saline group. 
b

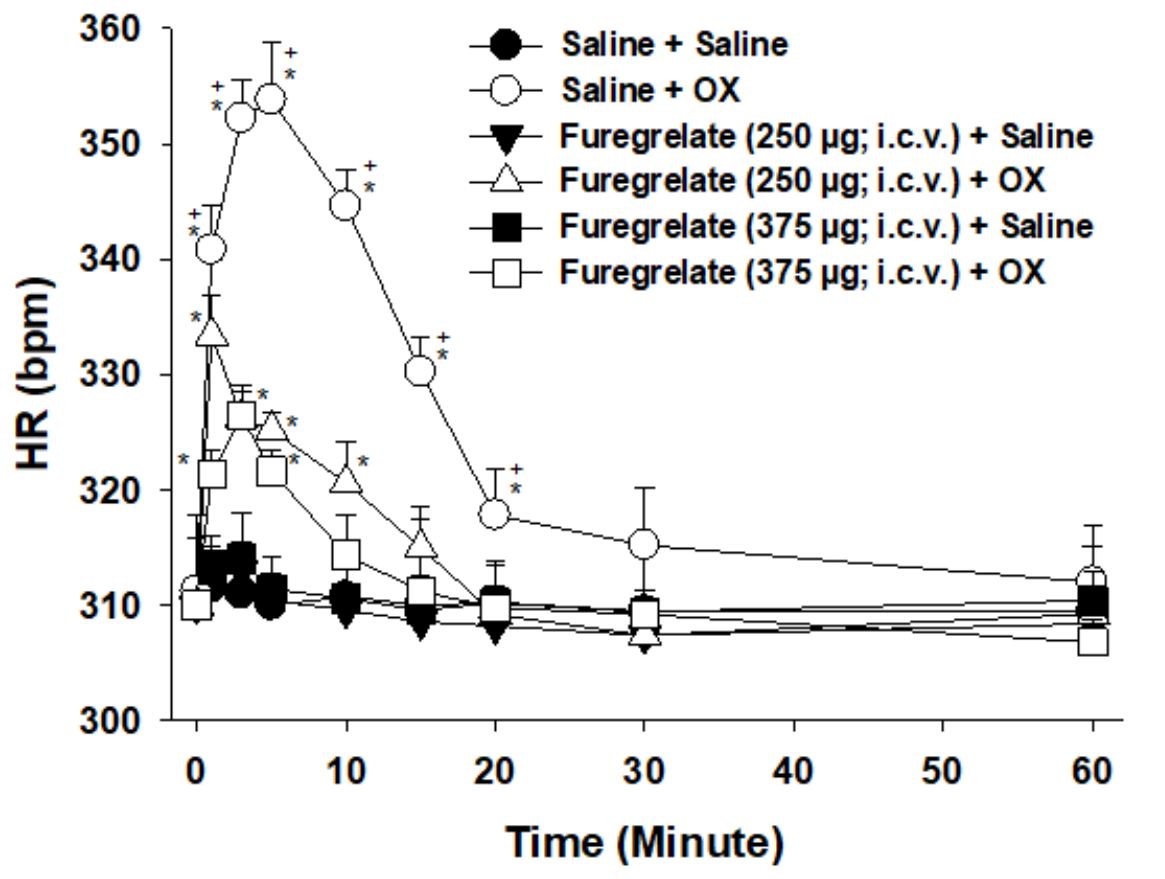

a

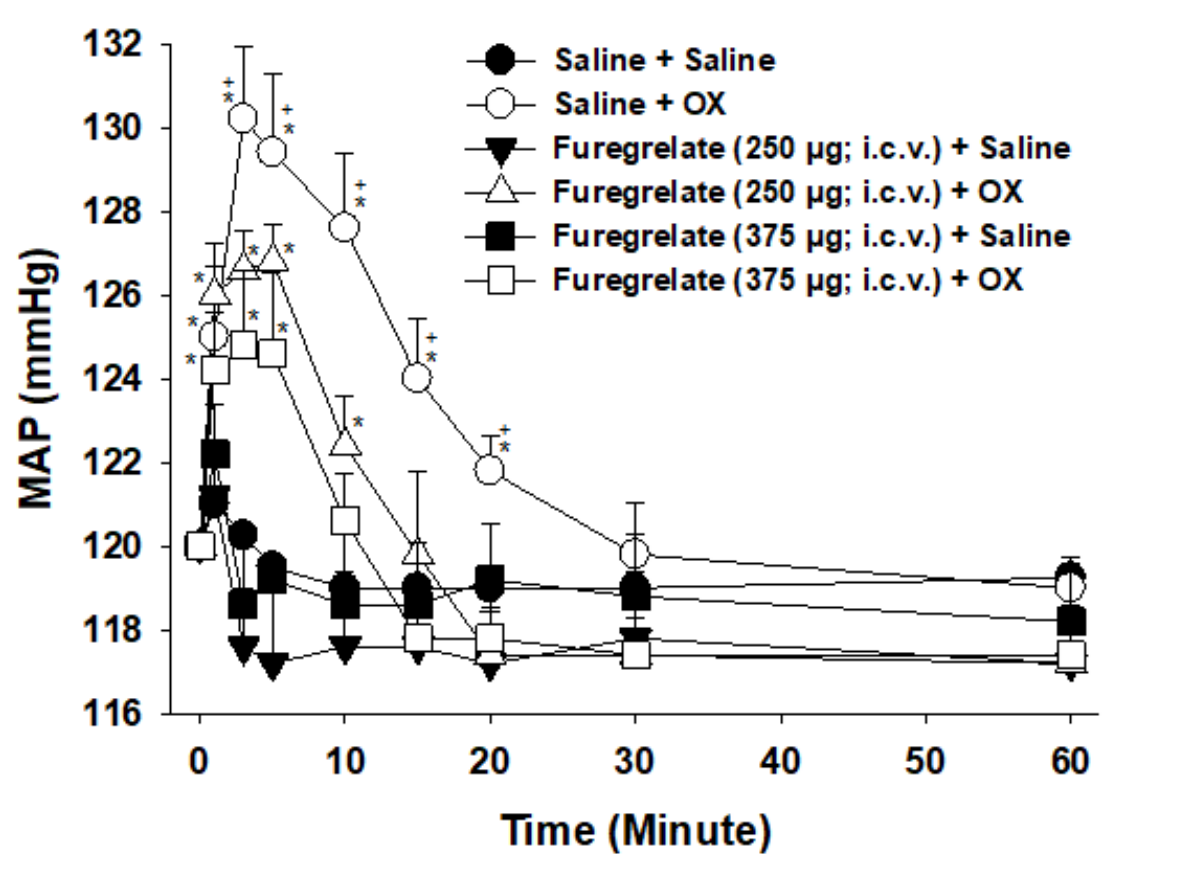

Figure 2. Inhibition of OX-produced cardiovascular effect with frugrelate

Furegrelate ( 250 and $375 \mu$; i.c.v.) or saline ( $5 \mu$; i.c.v.) was administered 5 min before OX (1.5 nmol; i.c.v.) or saline ( $5 \mu$; i.c.v.) injection, and then MAP (a) and HR (b) were monitored for the next 60 min. ${ }^{*} p<0.05$ was considered significantly different from the value of the "Saline + Saline" and "Furegrelate + Saline" groups, and ${ }^{+} p<0.05$ was considered significantly different from the value of the "Furegrelate + OX" group. 
Altinbas
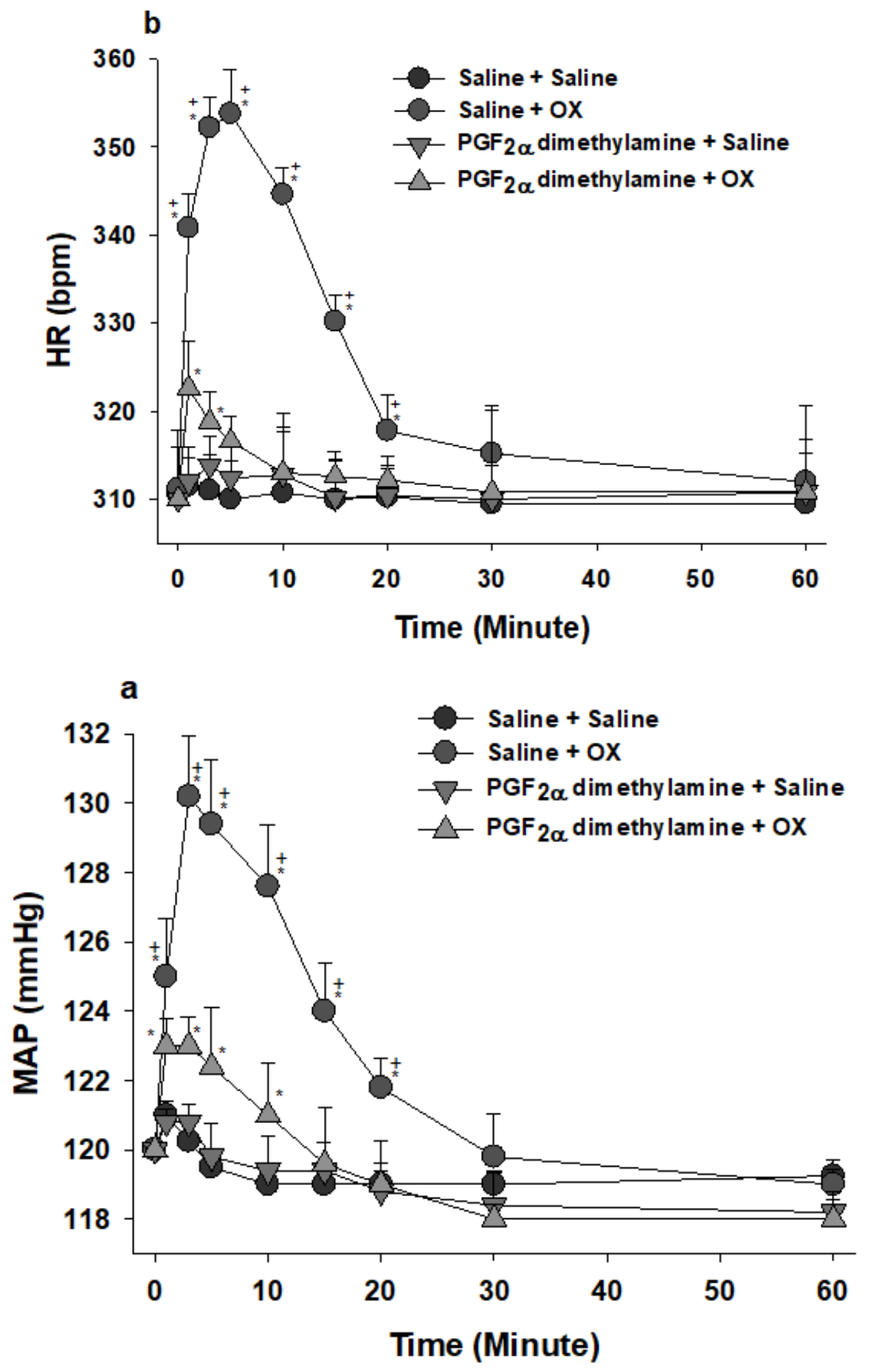

Figure 3. Inhibition of OX-produced cardiovascular effect with $\mathrm{PGF}_{2 \alpha}$ dimethylamine

$\mathrm{PGF}_{2 \alpha}$ dimethylamine (50 $\mu$ g; i.c.v.) or saline ( $5 \mu$ i; i.c.v.) was administered 5 min before OX (1.5 nmol; i.c.v.) or saline (5 $\mu$; i.c.v.) injection, and then MAP (a) and HR (b) were monitored for the next 60 min. ${ }^{*} p<0.05$ was considered significantly different from the value of the "Saline + Saline" and "PGF $2 \alpha$ dimethylamine + Saline" groups, and ${ }^{+} p<0.05$ was considered significantly different from the value of the " $\mathrm{PGF}_{2 \alpha}$ dimethylamine $+\mathrm{OX}$ " group. 
The Intermediation Role of Central Cyclooxygenase Products Txa $\mathrm{Tg}_{2 a}$, Pge, and Pgd in Orexin-Evoked Cardiovascular Effects

Altinbas
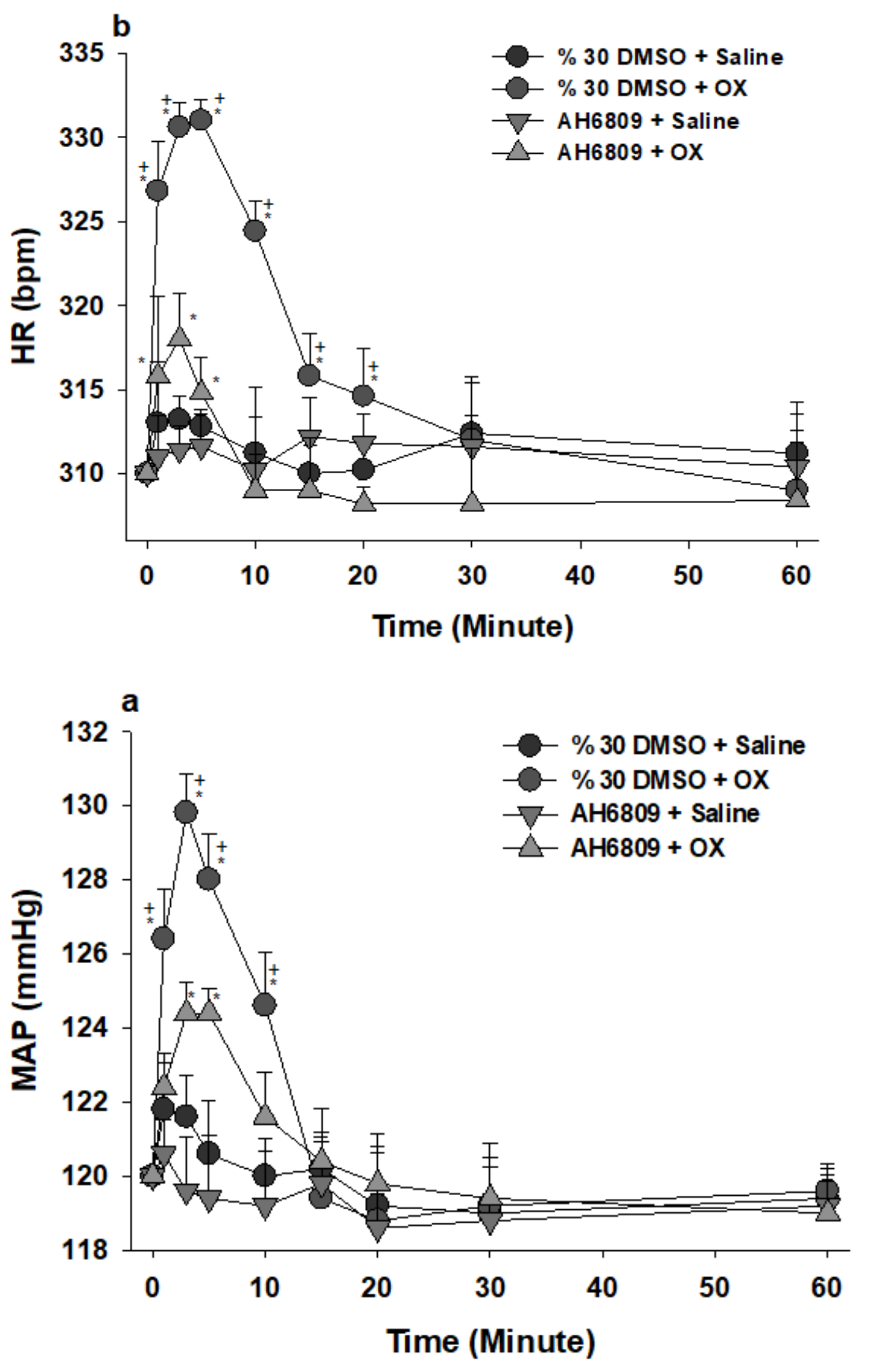

Figure 4. Inhibition of OX-produced cardiovascular effect with AH6809

AH6809 (10 $\mu$ g; i.c.v.), or 30\% DMSO (5 $\mu$ i; i.c.v.) was administered 5 min before OX (1.5 nmol; i.c.v.) or saline ( $5 \mu$ i; i.c.v.) injection, and then MAP (a) and HR (b) were monitored for the next 60 min. ${ }^{*} p<0.05$ was considered significantly different from the value of the "30\% DMSO + Saline" and "AH6809 + Saline" groups, and ${ }^{+} p<0.05$ was considered significantly different from the value of the "AH6809 + OX" group. 


\section{DISCUSSION}

The results showed that central injection of OX caused the pressor cardiovascular effect by increasing the levels of MAP and HR in normotensive conscious rats. The intriguing finding of the current study was that the cardiovascular effects of OX were mediated in part by $\mathrm{TXA}_{2}$, PGE, PGD and $\mathrm{PGF}_{2 \alpha}$, as AA-COX pathway.

OX produced by neurons precisely found in the dorso/lateral and perifornical regions of hypothalamus (De Lecea et al., 1998 pp. 322-327; Sakurai et al., 1998 pp. 573-585). OX system suggest that OXs are involved in many physiological functions such as appetite, sleep-wake cycle, arousal, stress, reward, and autonomic functions. In particular, the stimulation of OX receptors (OXRs) raises wakefulness (Sakurai et al., 2010, pp. 149-161), feeding, and energy metabolism (Girault et al., 2012, pp. 47-64) and stimulates sympathetic nerve activity (SNA) (Huang et al., 2010, pp. 522-529), controlling neuroendocrine and autonomic functions (Huang et al., 2010, pp. 522-529) such as sympathetic vasomotor tone (Li \& Pan, 2007, pp. 916-925) and blood pressure (Samson et al., 1999, pp. 248-253; Shahid et al., 2012b, pp. 159-184; Shirasaka et al., 1999, pp. 1780-1785). The effect of orexin in the organism is mediated by two G-protein coupled receptors, orexin-1 (OX1), and orexin-2 (OX2) receptor (Sakurai et al., 1998, pp. 573-585). OXRs have different distributions in the brain, and both are expressed in regions involved in autonomic function. Studies showed that OX1R and OX2R have been found in the bed nucleus of the stria terminalis and in many hypothalamic nuclei (including the paraventricular nucleus, PVN) and PVN express primarily OX2R. Besides, A5 and A6 noradrenergic group of the locus coeruleus and amygdala express primarily OX1R (Marcus et al., 2001, pp. 6-25). Also, OX1R has been located in the sympathetic preganglionic neurons (SPNs) of the thoracic cord more than OX2R (Van den Top et al., 2003, pp.809-821). Other reports stated that OX1R in the rostral ventromedial medulla (RVLM) area (Ciriello et al., 2003a, pp. 84-95) and both OX1R and OX2R in the C1 neurons pressor area of the RVLM (Shahid et al., 2012a, pp. 2292-2303). As seen in studies, it has been determined that orexin receptors are located in many regions of the central nervous system that are involved in the control of blood pressure. Although not the specific subject of our study, it can be thought that the pressor effects induced by orexin may be mediated by both OX's receptors.

The regulation of blood pressure is mainly controlled by the sympathetic nervous system and by many hypothalamic and brainstem neuronal groups (Guyenet, 2006, pp. 335-346). Recent studies show that the OX system is directly and/or indirectly effective in regulating blood pressure and SNA (Huang et al., 2010, pp. 522-529; Shahid et al., 2012b, pp. 159-184; Shirasaka et al., 2003, pp.639-651). First, Samson et al. (1999, pp. 248-253) and Shirasaka et al. (1999, pp.1780-1785) reported that OX-induced cardiovascular effects. In these studies, centrally administered OX was found to increase MAP, HR, and renal sympathetic nerve activity in both awake and anesthetized rats. The later findings proved beyond doubt that the central sympathoexcitatory effect plays a direct role in the cardiovascular effects of $\mathrm{OX}$ (Antunes et al., 2001, pp. 1801-1807; Dun et al., 2000, pp. 65-70). Intracisternal and intrathecal (T2-T3) administration of $\mathrm{OX}$ also elicited the same cardiovascular responses as i.c.v. injection (Antunes et al., 2001, pp. 1801-1807; Dun et al., 2000, pp. 65-70; Shahid et al., 2011, pp. 961973). Intragastric or intraperitoneal injection of OX antagonists to rats exposed to novelty stress caused alterations in tachycardic and pressor responses in rats (Beig et al., 2015, pp. 146-156). In addition, OX microinjections administered within different regions of the central autonomic network triggered changes in the levels of MAP and HR (Antunes et al., 2001,pp. 1801-1807; 


\section{The Intermediation Role of Central Cyclooxygenase Products Txa 2, Pgf $_{2 a}$, Pge, and Pgd in Orexin-Evoked Cardiovascular Effects}

Altinbas

Ciriello et al., 2003a, pp. 84-95; Ciriello et al., 2003b, pp. 1611-1620; Dun et al., 2000, pp. 6570; Huang et al., 2010, pp. 522-529; Shirasaka et al., 2001, pp. 1114-1118; Van den Top et al., 2003, pp. 809-821). At the same time, OX contributes to the regulation of blood pressure by sending excitatory projections to the main areas of the brain that synthesize epinephrine and norepinephrine (Marcus et al., 2001, pp. 6-25; Peyron et al., 1998, pp. 9996-10015). Furthermore, it is stated that adrenergic neurons in the RVLM, which send direct projections to SPNs and are involved in the tonic and phasic control of blood pressure and sympathetic activity, mediate the cardiovascular effects of orexin (Dampney, 1994, pp. 323-364; Guyenet et al., 1990, pp.1063-1074; Shirasaka et al., 1999, pp. 1780-1785). Additionally, studies report that orexin injected directly into the RVLM exerts its pressor effects on blood pressure by inhibiting vagal activity and increasing sympathetic outflow (Huang et al., 2010, pp. 522-529). Finally, it has been suggested that pre- OX knockout mice and rats with genetically ablated OX neurons have lower resting blood pressure compared to their wild-type controls (Kayaba et al., 2003, pp.581-593). These reports provide evidence that OX plays a role in cardiovascular control, as demonstrated in our study. It can be thought that OX, which we applied as i.c.v in our study, exerts its pressor effects on blood pressure by directly stimulating the norepinephrine and adrenergic systems in the central nervous system, as well as activating SPNs in the medulla, which is effective in cardiovascular control. Additionally, we have recently shown that COX and LOX pathways in the prostaglandinergic system are also stimulated by OX and affect blood pressure (Altinbas et al., 2021, pp.147239). In this study, we revealed that OX can also affect blood pressure through prostaglandin derivatives, which are in the lower step of the COX pathway.

Our recent study exhibited an interaction between the central OX and AA cascade (Altinbas et al., 2021, pp. 147239). In that study, we showed that i.c.v. injection of OX activates the COX and LOX pathways in cardiovascular responses. In the same article, we also performed a microdialysis study reporting that central administration of OX increased total extracellular AA metabolite levels in the posterior hypothalamus. However, this study did not explain which AA metabolites mediate the OX-induced cardiovascular effects. The most remarkable finding of this work is that $\mathrm{TXA}_{2}, \mathrm{PGE}, \mathrm{PGD}$, and $\mathrm{PGF}_{2 \alpha}$ as AA-COX metabolites partially mediate the $\mathrm{OX}$-induced cardiovascular responses. Thus, in our study, we showed that each of the specific antagonists we used partially inhibited OX's cardiovascular effects. However, we did not coinject all the antagonists used in the study. Nevertheless, the combined administration of all antagonists can completely abolish the blood pressure effects of OX, according to the results obtained. Previously, researchers have shown that centrally administered TXA 2 affected MAP and HR (Yalcin and Savci, 2004, pp. 177-187). In another study, it was reported that TXA 2 effectively activated the central sympatho-adrenomedullary outflow in rats (Murakam, et al., 2002, pp. 289-294). Recent research found that injection of PGE into the lateral ventricle or directly into the different brain areas altered cardiovascular scores (Hoffman et al., 1981, pp. 899-904; Siren, 1982a, pp.229-234). Besides, studies showed that centrally administered PGE $_{2}$ by injection or infusion into the cerebral ventricles in anesthetized or awake rats produces tachycardic effects, leading to increases in plasma norepinephrine and epinephrine, renin activity, and vasopressin levels (Feuerstein et al., 1982, pp. 335-342; Hoffman \& Schmis, 1979, pp. 159-169; Kondo et al., 1979, pp. 769-774; Takahashi \& Bunag, 1981, pp. 426-432). Moreover, reports indicated that the sympathetic nervous system mediates the hypertensive effects of central $\mathrm{PGE}_{2}$. In this regard, $\mathrm{PGE}_{2}$ 's pressor response has significantly attenuated by pretreatment with phenoxybenzamine, non-selective irreversible alpha-blocker, and by the 


\section{The Intermediation Role of Central Cyclooxygenase Products Txa 2, Pgf $_{2 a}$, Pge, and Pgd in Orexin-Evoked Cardiovascular Effects}

Altinbas

cervical section of the spinal cord (Takahashi and Bunag, 1981, pp. 426-432). Also, as noted earlier, the central application of $\mathrm{PGD}_{2}$ to the i.c.v in rats increased blood pressure and heart rate values due to central activation of the sympathetic nervous system (Förstermann et al., 1983, pp. 365-370; 1985, pp. 301-308; Siren, 1982a, pp.229-234). Also, $\mathrm{PGD}_{2}$ administration into the cerebrospinal fluid produced an acute, sympathetically mediated increase in blood pressure (Förstermann et al., 1985, pp. 301-308). In another study, $\mathrm{PGE}_{2}$ and $\mathrm{PGD}_{2}$ levels were significantly increased in the medulla oblongata and hypothalamus during hemorrhagic shock (Cernak et al., 1994, pp.363-375). Similarly, central PGF $_{2 \alpha}$ application caused pressor and positive chronotropic effects and tachycardia (Hoffman et al., 1981, pp. 899-904; Ono et al., 1983, pp. 23-28; Rao et al., 1987, pp. 7-14; Siren, 1982c, pp. 503-513). In a study in which $\mathrm{PGF}_{2 \alpha}$ was applied centrally, it was reported that the changes in cardiovascular parameters occurred via the sympathetic nervous system, and these changes were accompanied by increases in plasma epinephrine levels. Further, i.c.v. pretreatment with a $\mathrm{TXA}_{2}$ synthase inhibitor (Yalcin et al., 2006, pp. 207-212) or a PGD, PGE, or $\mathrm{PGF}_{2 \alpha}$ receptor antagonist (Erkan et al., 2017, pp. 117-124) partially blocked the cardiovascular effects of central injection of AA. As seen in the studies, it has been reported that AA metabolites play a role at least partially in the control of blood pressure. Furthermore, reports indicate that the above-mentioned AA metabolites control blood pressure through activation of the sympathetic system. Based on this information, we can think that the cardiovascular effects of orexin are mediated by TXA2, PGE, PGD, and $\mathrm{PGF}_{2 \alpha}$ by stimulating the sympathetic system.

\section{CONCLUSION}

In conclusion, the results of our work suggest that i.c.v. injection of OX elicits pressor and tachycardic cardiovascular responses. Interestingly, the result of the study shows that some AACOX pathway end products, including TXA 2 , PGE, PGD and $\mathrm{PGF}_{2 \alpha}$, partially mediate the OXinduced cardiovascular responses. Perhaps higher doses of furegrelate, $\mathrm{PGF}_{2 \alpha}$ dimethylamine, and AH6809 could block OX-induced cardiovascular responses, but higher doses of the drugs caused adverse effects in the animals. However, furegrelate (Yalcin et al., 2006, pp. 207-212), $\mathrm{PGF}_{2 \alpha}$ dimethylamine, and AH6809, used at the same dose as the one administered in the present study, were reported to partially block the cardiovascular responses created by AA. In our study, the partial mediation effects of TXA 2 , PGE, PGD, and $\mathrm{PGF}_{2 \alpha}$ as AA-metabolites on MAP and HR suggest that each metabolite might individually mediate the cardiovascular responses induced by OX. Although not specifically tested in the current study, prostacyclin, LOX, and other COX pathway products may play a role in cardiovascular effects formed by central administration of $\mathrm{OX}$ as another AA end product. In addition, the possible effects of subproducts of the central LOX pathway, which has an active role in cardiovascular control (Guvenc-Bayram et al., 2020, pp. 102670), on OX-produced cardiovascular responses may be investigated in future studies. Consequently, the OXergic system and the AA cascade, including the AA-COX pathway products, were found to interact in the central nervous system with respect to cardiovascular control.

\section{Acknowledgements}

This current study was carried out with generous support from TUBITAK (2140728). 


\section{REFERENCES}

Al-Barazanji, K.A., Wilson, S., Baker, J., Jessop, D.S., Harbuz, M.S. (2001). Central orexin-A activates hypothalamic-pituitary-adrenal axis and stimulates hypothalamic releasing factor and arginine vasopressin neurones in conscious rats. Journal of Neuroendocrinology, 13(5), 421424.

Altinbas, B., Guvenc-Bayram, G., Yalcin, M. (2021). The mediation of central cyclooxygenase and lipoxygenase pathways in orexin-induced cardiovascular effects. Brain Research, 1754, 147239.

Antunes, V.R., Brailoiu, G.C., Kwok, E.H., Scruggs, P., Dun, N.J. (2001). Orexins/hypocretins excite rat sympathetic preganglionic neurons in vivo and in vitro. American journal of physiology. Regulatory, integrative and comparative physiology, 281(6), 1801-1807.

Ariumi, H., Takano, Y., Masumi, A., Takahashi, S., Hirabara, Y. et al. (2002). Roles of the central prostaglandin EP3 receptors in cardiovascular regulation in rats. Neuroscience Letters, 324(1), 61-64.

Beig, M.I., Dampney, B.W., Carrive, P. (2015). Both Ox1r and Ox2r orexin receptors contribute to the cardiovascular and locomotor components of the novelty stress response in the rat. Neuropharmacology, 89, 146-156.

Cernak, I., Savić, J., Jovanović, M., Selaković, V. (1994). Brain PGD2 and PGE2 changes during posthaemorrhagic hypovolemia in rats. Vojnosanitetski pregled, 51(5), 363-375.

Ciriello, J., Li, Z., de Oliveira, C.V.R. (2003a). Cardioacceleratory responses to hypocretin-1 injections into rostral ventromedial medulla. Brain Research, 991(1-2), 84-95.

Ciriello, J., de Oliveira, C.V.R. (2003b). Cardiac effects of hypocretin-1 in nucleus ambiguus. American journal of physiology. Regulatory, integrative and comparative physiology, 284(6), 1611-1620.

Dampney, R.A. (1994). Functional organization of central pathways regulating the cardiovascular system. Physiological reviews, 74(2), 323-364.

De Lecea, L., Kilduff, T.S., Peyron, C., Gao, X., Foye, P.E. et al. (1998). The hypocretins: hypothalamus-specific peptides with neuroexcitatory activity. Proceedings of the National Academy of Sciences of the United States of America, 95(1), 322-327.

Dun, N.J., Le Dun, S., Chen, C.T., Hwang, L.L., Kwok, E.H. et al. (2000). Orexins: a role in medullary sympathetic outflow. Regulatory peptides, 96 (1-2), 65-70.

Erkan, L.G., Altinbas, B., Guvenc, G., Aydin, B., Niaz, N. et al. (2017). The acute cardiorespiratory effects of centrally injected arachidonic acid; the mediation of prostaglandin E, D and F2 $\alpha$. Respiratory physiology and neurobiology, 242, 117-124.

Feuerstein, G., Adelberg, S.A., Kopin, I.J., Jacobowitz, D.M. (1982). Hypothalamic sites for cardiovascular and sympathetic modulation by prostaglandin E2. Brain Research, 231(2), 33542 . 


\section{The Intermediation Role of Central Cyclooxygenase Products Txa 2, Pgf $_{2 a}$, Pge, and Pgd in Orexin-Evoked Cardiovascular Effects}

Altinbas

Förstermann, U., Heldt, R., Hertting, G. (1983). Effects of intracerebroventricular administration of prostaglandin D2 on behaviour, blood pressure and body temperature as compared to prostaglandins E2 and F2 alpha. Psychopharmacology (Berl), 80(4), 365-370.

Förstermann, U., Heldt, R., Hertting, G. (1985). Studies on the mechanism of central cardiovascular and temperature responses to prostaglandin D2. Prostaglandins, leukotrienes, and medicine, 18(3), 301-308.

Girault, E.M., Yi, C.X., Fliers, E., Kalsbeek, A. (2012). Orexins, feeding, and energy balance. Progress in brain research, 198, 47-64.

Guvenc-Bayram, G., Altinbas, B., Iqbal, A., Cerci, E., Udum, D. et al. (2020). Intracerebroventricularly injected nesfatin-1 activates central cyclooxygenase and lipoxygenase pathways. Autonomic Neuroscience, 226, 102670.

Guyenet, P.G., Darnall, R.A., Riley, T.A. (1990). Rostral ventrolateral medulla and sympathorespiratory integration in rats. The American journal of physiology, 259(5 Pt 2), 1063 74.

Guyenet, P.G. (2006). The sympathetic control of blood pressure. Nature reviews. Neuroscience, 7(5), 335-346.

Hoffman, W.E., Schmid, P.G. (1979). Cardiovascular and antidiuretic effects of central prostaglandin E2. The Journal of physiology, 288, 159-169.

Hoffman, W.E., Leavitt, M.L., Albrecht, R.F., Miletich, D.J. (1981). Central cardiovascular activity of prostaglandin E2, prostaglandin F2 alpha and prostacyclin. Prostaglandins, 21(6), 899-904.

Huang, S.C., Dai, Y.W., Lee, Y.H., Chiou, L.C., Hwang, L.L. (2010). Orexins depolarize rostral ventrolateral medulla neurons and increase arterial pressure and heart rate in rats mainly via orexin 2 receptors. The Journal of pharmacology and experimental therapeutics, 334(2), 522529.

Jochem, J. (2009). Orexin type 1 receptor antagonist SB 334867 inhibits the central histamineinduced resuscitating effect in rats subjected to haemorrhagic shock. Inflammation research : official journal of the European Histamine Research Society, 58(Suppl1), 36-7.

Kayaba, Y., Nakamura, A., Kasuya, Y., Ohuchi, T., Yanagisawa, M. et al. (2003). Attenuated defense response and low basal blood pressure in orexin knockout mice. American journal of physiology. Regulatory, integrative and comparative physiology, 285(3), 581-593.

Kondo, K., Okuno, T., Saruta, T., Kato, E. (1979). Effects of intracerebroventricular administration of prostaglandins I2, E2, F2 alpha and indomethacin on blood pressure in the rat. Prostaglandins, 17(5), 769-774.

Li, D.P., Pan, H.L. (2007). Glutamatergic inputs in the hypothalamic paraventricular nucleus maintain sympathetic vasomotor tone in hypertension. Hypertension, 49(4), 916-925. 


\section{The Intermediation Role of Central Cyclooxygenase Products Txa 2, Pgf $_{2 a}$, Pge, and Pgd in Orexin-Evoked Cardiovascular Effects}

Altinbas

Lin, Y., Matsumura, K., Tsuchihashi, T., Abe, I., Lida, M. (2002). Chronic central infusion of orexin-A increases arterial pressure in rats. Brain research bulletin, 57(5), 619-622.

Marcus, J.N., Aschkenasi, C.J., Lee, C.E., Chemelli, R.M., Saper, C.B. et al. (2001). Differential expression of orexin receptors 1 and 2 in the rat brain. The Journal of comparative neurology, 435(1), 6-25.

Murakami, Y., Okada, S., Nishihara, M., Yokotani, K. (2002). Roles of brain prostaglandin E2 and thromboxane A2 in the activation of the central sympatho-adrenomedullary outflow in rats. European journal of pharmacology, 452(3), 289-294.

Nambu, T., Sakurai, T., Mizukami, K., Hosoya, Y., Yanagisawa, M. et al. (1999). Distribution of orexin neurons in the adult rat brain. Brain Research, 827(1-2), 243-260.

Ono, N., Furukawa, T. (1983). Central effects of prostaglandin F2 alpha on the cardiovascular system in the rat. Pharmacology, 27(1), 23-28.

Osborne, P.G., Kurosawa, M. (1994). Perfusion of the preoptic area with muscimol or prostaglandin E2 stimulates cardiovascular function in anesthetized rats. Journal of the autonomic nervous system, 46(3), 199-205.

Peyron, C., Tighe, D.K., van den Pol, A.N., de Lecea, L., Heller, H.C. et al. (1998). Neurons containing hypocretin (orexin) project to multiple neuronal systems. The Journal of neuroscience : the official journal of the Society for Neuroscience, 18(23), 9996-10015.

Rao, T.S., Seth, S.D., Manchanda, S.C., Nayar, U. (1987). The involvement of the sympathetic nervous system in the centrogenic pressor and tachycardiac effects of prostaglandins E2 and F2 alpha in anaesthetised cats. Brain Research, 435(1-2), 7-14.

Sakurai, T., Amemiya, A., Ishii, M., Matsuzaki, I., Chemelli, R.M. et al. (1998). Orexins and orexin receptors: a family of hypothalamic neuropeptides and $\mathrm{G}$ protein-coupled receptors that regulate feeding behavior. Cell, 92(4), 573-585.

Sakurai, T., Mieda, M., Tsujino, N. (2010). The orexin system: roles in sleep/wake regulation. Annals of the New York Academy of Sciences, 1200, 149-161.

Samson, W.K., Gosnell, B., Chang, J.K., Resch, Z.T., Murphy, T.C. (1999). Cardiovascular regulatory actions of the hypocretins in brain. Brain Research, 831(1-2), 248-253.

Shahid, I.Z., Rahman, A.A., Pilowsky, P.M. (2011). Intrathecal orexin A increases sympathetic outflow and respiratory drive, enhances baroreflex sensitivity and blocks the somatosympathetic reflex. British journal of pharmacology, 162(4), 961-973.

Shahid, I.Z., Rahman, A.A., Pilowsky, P.M. (2012a). Orexin A in rat rostral ventrolateral medulla is pressor, sympatho-excitatory, increases barosensitivity and attenuates the somatosympathetic reflex. British journal of pharmacology, 165(7), 2292-303.

Shahid, I.Z., Rahman, A,A,, Pilowsky, P.M. (2012b). Orexin and central regulation of cardiorespiratory system. Vitamines and Hormones, 89, 159-84. 
Altinbas

Shirasaka, T., Nakazato, M., Matsukura, S., Takasaki, M., Kannan, H. (1999). Sympathetic and cardiovascular actions of orexins in conscious rats. The American journal of physiology, 277(6), 1780-5.

Shirasaka, T., Miyahara, S., Kunitake, T., Jin, Q.H., Kato, K. et al. (2001). Orexin depolarizes rat hypothalamic paraventricular nucleus neurons. American journal of physiology. Regulatory, integrative and comparative physiology, 281(4), 1114-1118.

Shirasaka, T., Takasaki, M., Kannan, H. (2003). Cardiovascular effects of leptin and orexins. American journal of physiology. Regulatory, integrative and comparative physiology, 284(3), 639-651.

Siren, A.L. (1982a). Central cardiovascular and thermal effects of prostaglandin E2 in rats. Acta physiologica Scandinavica, 116(3), 229-234.

Siren, A.L. (1982b). Central cardiovascular and thermal effects of prostaglandin D2 in rats. Prostaglandins, leukotrienes, and medicine, 8(4), 349-359.

Siren, A.L. (1982c). Differences in the central actions of arachidonic acid and prostaglandin F2 $\alpha$ between spontaneously hypertensive and normotensive rats. Life Sciences, 30(6), 503-513.

Takahashi, H., Bunag, R.D. (1981). Pressor responses to centrally-administered prostaglandin E2 in spontaneously hypertensive rats. Hypertension, 3(4), 426-432.

Tassoni, D., Kaur, G., Weisinger, R.S., Sinclair, A.J. (2008). The role of eicosanoids in the brain. Asia Pacific journal of clinical nutrition, 17 (Suppl1), 220-228.

Van den Top, M., Nolan, M.F., Lee, K., Richardson, P.J., Buijs, R.M. et al. (2003). Orexins induce increased excitability and synchronisation of rat sympathetic preganglionic neurones. The Journal of Physiology, 549(Pt 3), 809-821.

Wasserman, M.A., DuCharme, D.W., Griffin, R.L., DeGraaf, G.L., Robinson, F.G. (1977). Bronchopulmonary and cardiovascular effects of prostaglandin D2 in the dog. Prostaglandins, 13(2), 255-269.

Willie, J.T., Chemelli, R.M., Sinton, C.M., Yanagisawa, M. (2001). To eat orto sleep? Orexin in the regulation of feeding and wakefulness. Annual review of neuroscience, 24, 429-458.

Wlodawer, P., Samuelsson, B. (1973). On the organization and mechanism of prostaglandin synthetase. The Journal of biological chemistry, 248(16), 5673-5678.

Yalcin, M., Savci, V. (2004). Restoration of blood pressure by centrally injected U-46619, a thromboxane $\mathrm{A}_{2}$ analog, in haemorhaged hypotensive rats: investigation of different brain areas. Pharmacology, 70(4), 177-187.

Yalcin, M., Ak, F., Erturk, M. (2006). The role of central thromboxane A2 in cardiovascular effects of a phospholipase A2 activator melittin administrated intracerebroventricularly in normotensive conscious rats. Neuropeptides, 40 (3), 207-212. 
Altinbas

Yalcin, M., Erturk, M. (2007). The involvement of the central cholinergic system in the pressor and bradycardic effects of centrally administrated melittin in normotensive conscious rats. Neuropeptides, 41(2), 103-110.

Yalcin, M., Aydın, C., Savci, V. (2009). Cardiovascular effect of peripheral injected melittin in normotensive conscious rats: mediation of the central cholinergic system. Prostaglandins Leukot Essent Fatty Acids, 81(5-6), 341-347.

Yalcin, M., Aydın, C. (2009). Cardiovascular effects of centrally administered arachidonic acid in haemorrhage-induced hypotensive rats: investigation of a peripheral mechanism. Clinical and experimental pharmacology \& physiology, 36(4), 447-453. 